Supporting Information for:

\title{
A Cu${ }_{2}{ }_{2}$ PARACEST Contrast Agent Enabled by Magnetic Exchange Coupling
}

\author{
Kang Du and T. David Harris* \\ Department of Chemistry, Northwestern University, 2145 Sheridan Road, \\ Evanston IL 60208-3113 \\ Email: dharris@northwestern.edu \\ J. Am. Chem. Soc.
}

\section{Table of Contents}

$\begin{array}{lr}\text { Experimental Section } & \text { S2 }\end{array}$

Table S1 | Crystallographic data for 1 $\quad$ S7

Scheme S1 | Synthesis of precursors for HL $\quad$ S8

Figure S1 | UV/Visible spectra of $\mathrm{HL}+\mathrm{Cu}^{2+} \quad$ S9

Figure S2 | Appearance of peak at $398 \mathrm{~nm}$ vs $\mathrm{Cu}^{2+}$ added $\quad \mathbf{S 1 0}$

Figure S3 | UV/Visible titration spectra of $\mathrm{HL}^{-\mathrm{Cu}^{2+}+\mathrm{K}_{4}\left(\mathrm{P}_{2} \mathrm{O}_{7}\right)} \quad \mathbf{S 1 1}$

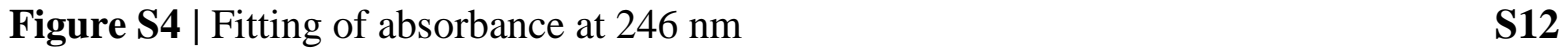

Figure S5 | Diffuse-reflectance spectrum for a solid sample of $1 \quad$ S13

Figure S6 | ESI mass spectrum of $\mathbf{1}$ in $\mathrm{H}_{2} \mathrm{O} \quad \mathbf{S 1 4}$

$\begin{array}{lr}\text { Figure S7 | UV/Visible spectra of } 2 & \text { S15 }\end{array}$

Figure S8 | Diffuse-reflectance spectrum for a solid sample of $2 \quad$ S16

Figure S9 | UV/Visible spectra for $\mathbf{1}$ in $\mathrm{H}_{2} \mathrm{O}$ and 1:1 $\mathrm{H}_{2} \mathrm{O} /$ glycerol $\quad$ S17

Figure S10 | X-band EPR spectrum of $\mathbf{1}$ in 1:1 $\mathrm{H}_{2} \mathrm{O} /$ glycerol $\quad$ S18

Figure S11 $\mid{ }^{1} \mathrm{H}$ NMR spectra of $\mathbf{1}$ and $\mathbf{2}$ in $\mathrm{D}_{2} \mathrm{O}$ and buffered $\mathrm{H}_{2} \mathrm{O}$ at pH $7 \quad$ S19

Figure S12 $\mid$ CEST spectrum of 1 at $25^{\circ} \mathrm{C} \quad$ S20

Figure S13 | Omega plot for 1 at $37^{\circ} \mathrm{C} \quad$ S21

Figure S14 | Cyclic voltammogram for $\mathbf{1}$ at ambient temperature $\quad$ S22

Figure S15 | UV/Visible spectra of $\mathbf{1}$ at different $\mathrm{pH} \quad \mathbf{S 2 3}$

Figure S16 | UV/Visible spectra of 1 with $\mathrm{Na}_{2} \mathrm{CO}_{3}$ and $\mathrm{NaH}_{2} \mathrm{PO}_{4} \quad$ S24

Figure S17 | UV/Visible spectra of 1 with $\mathrm{Zn}^{2+} \quad \mathbf{S 2 5}$

Figure S18 | IR spectra of 1 and $2 \quad$ S26

$\begin{array}{lr}\text { References } & \text { S27 }\end{array}$ 


\section{Experimental Section}

General considerations. Unless otherwise specified, chemicals and solvents were purchased from commercial vendors and used without further purification. Deuterated solvents were purchased from Cambridge Isotope Laboratories. When necessary for moisture sensitive experiments, glassware was flame dried or stored in an oven at $150{ }^{\circ} \mathrm{C}$ for at least 4 hours, followed by cooling in a desiccator. Air- and water-free manipulations were carried out using standard Schlenk techniques. Acetonitrile was dried using a commercial solvent purification system from Pure Process Technology and stored over $4 \AA$ molecular sieves prior to use. Water was obtained from a purification system from EMD Millipore. Elemental analysis was conducted by Midwest Microlab Inc. Preparative reverse-phase HPLC was performed on a Waters $19 \times 250 \mathrm{~mm}^{2} \mathrm{Xbridge}$ C18 Column, using the Varian Prostar 500 system equipped with a Varian 363 fluorescence detector and a Varian 335 UV/Visible Detector. During HPLC, water was used as solvent A and acetonitrile as solvent B. The absorbances at 220 and $285 \mathrm{~nm}$ were monitored. Anhydrous hydrogen chloride gas was generated by adding concentrated hydrochloric acid to a stirring solution of concentrated sulfuric acid. The gas was passed through a bubbler filled with sulfuric acid.

Synthesis of 2,6-bis(bromomethyl)-4-methylphenol. This compound was synthesized following a modified literature procedure. ${ }^{1}$ Para-cresol $(9.7 \mathrm{~g}, 0.090 \mathrm{~mol})$ was dissolved in an aqueous solution $(18 \mathrm{~mL})$ of sodium hydroxide $(4.5 \mathrm{~g}, 0.11 \mathrm{~mol})$. To this solution was added with stirring a $37 \%$ aqueous solution of formaldehyde $(18 \mathrm{~mL})$, and the resulting light yellow solution was stirred for $12 \mathrm{~h}$ at ambient temperature to give a white solid precipitate. The solid was collected by filtration and then was dissolved in $\mathrm{H}_{2} \mathrm{O}(200 \mathrm{~mL})$, and the ensuing solution was adjusted to $\mathrm{pH} 6$ with glacial acetic acid. Upon stirring for 15 minutes, a white solid precipitated and was collected by filtration. This solid was dissolved in a solution of $37 \% \mathrm{HBr}$ in acetic acid $(40 \mathrm{~mL})$. After stirring for $24 \mathrm{~h}$, the resulting mixture was diluted with $\mathrm{H}_{2} \mathrm{O}(40 \mathrm{~mL})$, stirred for an additional 30 minutes, and then filtered to give the product as an off-white solid $(9.0 \mathrm{~g}, 34 \%)$. ${ }^{1} \mathrm{H} \mathrm{NMR}(\mathrm{MeCN}-$ $\left.d_{3}\right): 2.24(\mathrm{~s}, 3 \mathrm{H}), 4.61(\mathrm{~s}, 4 \mathrm{H}), 7.15(\mathrm{~s}, 2 \mathrm{H})$.

Synthesis of 2,2'-iminobis(acetamide). This compound was synthesized following a modified literature procedure. ${ }^{2}$ Iminodiacetonitrile $(5.0 \mathrm{~g}, 0.053 \mathrm{~mol})$ was suspended in anhydrous isopropanol $(100 \mathrm{~mL})$. Anhydrous $\mathrm{HCl}$ gas was bubbled into this suspension, and the mixture was stirred at $50{ }^{\circ} \mathrm{C}$ for $15 \mathrm{~h}$. The resulting yellow mixture was then filtered to isolate an off-white solid. The solid was dissolved in $\mathrm{H}_{2} \mathrm{O}(40 \mathrm{~mL})$, and the solution was adjusted to $\mathrm{pH} 10$ with $\left(\mathrm{NH}_{4}\right) \mathrm{OH}$. The solution was evaporated to dryness, and the remaining brown solid was dissolved in $\mathrm{H}_{2} \mathrm{O}(18 \mathrm{~mL})$. The resulting dark brown solution was added to acetone $(120 \mathrm{~mL})$ with stirring, giving an off-white precipitate. Upon stirring for 10 minutes, the off-white solid was collected by filtration to give the product as an off-white solid $(3.0 \mathrm{~g}, 45 \%){ }^{1} \mathrm{H}$ NMR (DMSO- $\left.d_{6}\right): 3.67$ (s, 4H), $7.50(\mathrm{~s}, 2 \mathrm{H}), 7.84(\mathrm{~s}, 2 \mathrm{H})$.

Synthesis of $\quad N, N^{\prime}$-[(2-hydroxy-5-methyl-1,3-phenylene)bis(methylene)]bis[N(carboxymethyl)glycinamide] (HL). Under a dinitrogen atmosphere, $N, N$-diisopropylethylamine (1.47 g, $11.4 \mathrm{mmol}$ ) and 2,2'-iminobis(acetamide) (1.50 g, $11.4 \mathrm{mmol}$ ) were suspended in MeCN $(200 \mathrm{~mL})$. The suspension was heated to reflux, and to it was added dropwise with stirring a 
solution of 2,6-bis(bromomethyl)-4-methylphenol (1.12 g, $3.81 \mathrm{mmol}$ ) in $\mathrm{MeCN}$ (20 mL) over the course of $24 \mathrm{~h}$ to give a dark brown slurry. The reaction mixture was evaporated to dryness, and the remaining brown residue was dissolved in a $10 \%$ aqueous $\mathrm{MeOH}$ solution $(18 \mathrm{~mL})$ and subsequently purified by $\mathrm{C} 18$ reverse-phase $\mathrm{HPLC}$ using $\mathrm{H}_{2} \mathrm{O}$ and $\mathrm{MeCN}$ as eluents. Evaporation of the resulting solution gave $\mathrm{HL}$ as an off-white solid $(0.205 \mathrm{~g}, 13 \%)$. ESI-MS: $395.101\left(\mathrm{M}+\mathrm{H}^{+}\right)$. ${ }^{1} \mathrm{H}$ NMR $\left(\mathrm{MeOH}-d_{4}\right): 2.23(\mathrm{~s}, 3 \mathrm{H}), 3.35$ (s, 8H), $3.82(\mathrm{~s}, 4 \mathrm{H}), 6.96$ (s, 2H). UV/Visible absorption spectrum: $285 \mathrm{~nm}\left(\varepsilon=2660 \mathrm{M}^{-1} \mathrm{~cm}^{-1}\right)$. FT-IR (ATR, $\left.\mathrm{cm}^{-1}\right)$ : 3172 (m, broad); $1674(\mathrm{~s}) ; 1648(\mathrm{~s})$; 1598 (m); 1480 (m); 1411 (m); 1340 (m); 1254 (m); 1209 (m); 1111 (m); 1009 (m); 859 (m); 786 (m).

Synthesis of $\mathbf{H}\left[\mathrm{LCu}_{2}\left(\mathrm{P}_{2} \mathrm{O}_{7}\right)\right] \cdot \mathbf{0 . 5} \mathrm{KNO}_{3} \cdot \mathbf{3} \mathrm{H}_{2} \mathrm{O}(\mathbf{1}) \cdot \mathrm{Cu}\left(\mathrm{NO}_{3}\right)_{2} \cdot 3 \mathrm{H}_{2} \mathrm{O}(12 \mathrm{mg}, 0.051 \mathrm{mmol})$ was dissolved in $\mathrm{H}_{2} \mathrm{O}(0.5 \mathrm{~mL})$, and the resulting solution was added to a stirring solution of HL (10 $\mathrm{mg}, 0.025 \mathrm{mmol})$ in $\mathrm{H}_{2} \mathrm{O}(0.5 \mathrm{~mL})$ to give a brown solution. The solution was stirred for 15 minutes, and then a solution of $\mathrm{K}_{4}\left(\mathrm{P}_{2} \mathrm{O}_{7}\right)(8.4 \mathrm{mg}, 0.025 \mathrm{mmol})$ in $\mathrm{H}_{2} \mathrm{O}(0.5 \mathrm{~mL})$ was added. After an additional 15 minutes of stirring, the $\mathrm{pH}$ of the brown solution was adjusted to 7 through addition of a ca. 5\% aqueous $\mathrm{KOH}$ solution. The ensuing brown solution was stirred for 30 minutes and then filtered through a $0.22 \mu \mathrm{m}$ nylon membrane. Slow evaporation of the resulting brown solution gave brown plate-shaped crystals of $\mathbf{1}(11 \mathrm{mg}, 37 \%)$ suitable for single-crystal X-ray diffraction analysis. UV/Visible absorption spectrum: $302 \mathrm{~nm}\left(\varepsilon=4470 \mathrm{M}^{-1} \mathrm{~cm}^{-1}\right), 432 \mathrm{~nm}\left(\varepsilon=742 \mathrm{M}^{-1}\right.$ $\left.\mathrm{cm}^{-1}\right), 771 \mathrm{~nm}\left(\varepsilon=107 \mathrm{M}^{-1} \mathrm{~cm}^{-1}\right)$. FT-IR (ATR, $\left.\mathrm{cm}^{-1}\right)$ : 3154 (m, broad); 1667 (s); 1614 (s); 1476 (m); 1350 (s); 1317 (s); 1278 (w); 1093 (s); 1020 (m); 876 (m); 803 (w) (see Figure S14). Due to the co-crystallization of small but inconsistent impurities of $\mathrm{KNO}_{3}$, satisfactory elemental analysis could not be obtained for 1 . However, addition of EtOH $(5 \mathrm{~mL})$ to a stirred concentrated $(0.5 \mathrm{~mL})$ brown solution of crystallization from above gave $\mathrm{K}\left[\mathrm{LCu}_{2}\left(\mathrm{P}_{2} \mathrm{O}_{7}\right)\right] \cdot 3 \mathrm{KNO}_{3} \cdot 4 \mathrm{H}_{2} \mathrm{O} \cdot 0.6 \mathrm{EtOH}$ as a light brown precipitate. Anal. Calcd. for $\mathrm{C}_{18.2} \mathrm{H}_{36.6} \mathrm{Cu}_{2} \mathrm{~N}_{9} \mathrm{O}_{25.6} \mathrm{P}_{2} \mathrm{~K}_{4}$ : C, 19.23; H, 3.25; N, $11.09 \%$. Found: C, 19.21; H, 2.63; N, 10.59\%.

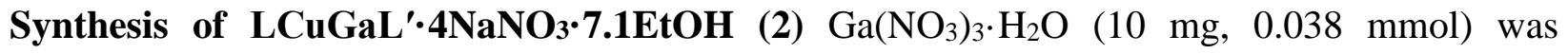
dissolved in $\mathrm{H}_{2} \mathrm{O}(0.5 \mathrm{~mL})$, and the resulting solution was added to a stirring solution of HL (15 $\mathrm{mg}, 0.038 \mathrm{mmol})$ in $\mathrm{H}_{2} \mathrm{O}(0.5 \mathrm{~mL})$ to give a pale yellow solution. $\mathrm{Cu}\left(\mathrm{NO}_{3}\right)_{2} \cdot 3 \mathrm{H}_{2} \mathrm{O}(9.2 \mathrm{mg}, 0.038$ $\mathrm{mmol})$ in $\mathrm{H}_{2} \mathrm{O}(1.0 \mathrm{~mL})$ was added to the above solution dropwise. The light brown solution was stirred for 15 minutes, and then a solution of $\mathrm{Na}_{(\mathrm{H}}\left(\mathrm{H}_{3} \mathrm{~L}^{\prime}\right) \cdot 3 \mathrm{H}_{2} \mathrm{O}(12 \mathrm{mg}, 0.038 \mathrm{mmol})$ in $\mathrm{H}_{2} \mathrm{O}(0.5$ $\mathrm{mL}$ ) was added. After an additional 15 minutes of stirring, the $\mathrm{pH}$ of the brown solution was adjusted to 7 through addition of a ca. $5 \%$ aqueous $\mathrm{NaOH}$ solution. The ensuing brown solution was stirred for $30 \mathrm{~min}$ and then filtered through a $0.22 \mu \mathrm{m}$ nylon membrane. The filtrate was concentrated under reduced pressure to a volume of $0.5 \mathrm{~mL}$, addition of $\mathrm{EtOH}(5 \mathrm{~mL})$ to this solution with stirring gave $2(13 \mathrm{mg}, 23 \%)$ as a yellow precipitate. Anal. Calcd. for $\mathrm{C}_{35.2} \mathrm{H}_{77.6} \mathrm{CuGaN}_{12} \mathrm{O}_{34.1} \mathrm{P}_{2} \mathrm{Na}_{4}: \mathrm{C}, 28.15 ; \mathrm{H}, 5.21 ; \mathrm{N}, 11.19 \%$. Found: $\mathrm{C}, 27.80 ; \mathrm{H}, 4.33 ; \mathrm{N}, 10.85 \%$. UV/Visible absorption spectrum: $363 \mathrm{~nm}\left(\varepsilon=1070 \mathrm{M}^{-1} \mathrm{~cm}^{-1}\right), 418 \mathrm{~nm}\left(\varepsilon=297 \mathrm{M}^{-1} \mathrm{~cm}^{-1}\right), 784$ $\mathrm{nm}\left(\varepsilon=75 \mathrm{M}^{-1} \mathrm{~cm}^{-1}\right)$. FT-IR (ATR, $\left.\mathrm{cm}^{-1}\right)$ : 3154 (m, broad); 1667 (s); 1614 (s); 1483 (s); 1448 (w); 1319 (s); 1279 (w); 1116 (s); 1070 (s); 999 (m); 875 (m); 815 (w) (see Figure S18).

$\mathrm{X}$-ray structure determination. A single crystal of $\mathbf{1}$ was directly coated with Paratone-N oil and mounted on a MicroMounts ${ }^{\mathrm{TM}}$ rod. The crystallographic data were collected at $100 \mathrm{~K}$ on a Bruker 
APEX II diffractometer equipped with MoK $\alpha$ sealed tube source. Raw data were integrated and corrected for Lorentz and polarization effects using Bruker APEX2 v. 2009.1. ${ }^{3}$ The program SADABS was use to apply absorption correction. ${ }^{4}$ Space group assignments were determined by examining systematic absences, E-statistics and successive refinement of the structure. Structures were solved by SHELXT using direct methods and refined by SHELXL within the OLEX interface. ${ }^{4} \mathrm{H}_{2} \mathrm{O}$ solvent molecules were severely disordered and could not be modeled properly. Therefore, the program SQUEEZE, ${ }^{5}$ a component of PLATON, ${ }^{6}$ was used to calculate solvent disorder area. A total of $25 \mathrm{H}_{2} \mathrm{O}$ molecules were estimated based on 251 electrons in a void volume of $665.1 \AA^{3}$. Partially occupied solvent $\mathrm{H}_{2} \mathrm{O}$ molecules that were potentially hydrogen bonded were not considered by SQUEEZE and therefore were modeled isotropically. Thermal parameters for all other non-hydrogen atoms were refined anisotropically. Crystallographic data and the details of data collection are listed in Table S1.

${ }^{1}$ H NMR experiments. Variable temperature ${ }^{1} \mathrm{H}$ NMR spectra were collected on an Agilent DD2 $500 \mathrm{MHz}(11.75 \mathrm{~T})$ system. $T_{1}$ and $T_{2}$ values were obtained from the preset pulse sequence in the program vnmr and processed by the program MNOVA. Due to radiation damping, the instrument was detuned (tuning at $490 \mathrm{MHz}$ ) to perform the $T_{1}$ measurements for water protons.

CEST experiments. Variable temperature CEST experiments were performed on an Agilent DD2 $500 \mathrm{MHz}(11.75 \mathrm{~T})$ system. Samples containing $10 \mathrm{mM}$ of 1 and $30 \mathrm{mM}$ of 2 in $50 \mathrm{mM}$ of HEPES at $\mathrm{pH} 7$ were used for CEST experiments. Z-spectra (CEST spectra) were obtained according to the following protocol. NMR spectra were acquired using the presaturation pulse applied for $2 \mathrm{~s}$ at a power level of $21 \mu \mathrm{T}$. The saturation frequency offsets were screened with a step increase of $0.4 \mathrm{ppm}$. The obtained NMR spectra were plotted as normalized water intensity against frequency offset to produce a Z-spectrum. Direct saturation of the water signal was set to $0 \mathrm{ppm}$. $\mathrm{D}_{2} \mathrm{O}$ was placed in an inner capillary to lock the sample. Exchange rate constants were calculated based off a reported method. ${ }^{7}$ The NMR spectra were acquired at various presaturation powers ranging from 7.4 to $21 \mu \mathrm{T}$ applied for $5 \mathrm{~s}$.

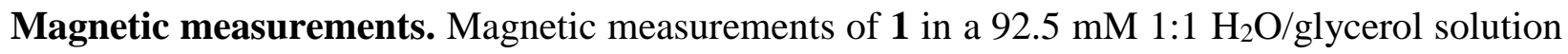
were carried out using a Quantum Design MPMS-XL SQUID magnetometer. Absorption spectra of $\mathbf{1}$ in $\mathrm{H}_{2} \mathrm{O}$ and in 1:1 $\mathrm{H}_{2} \mathrm{O} /$ glycerol confirmed the preservation of the structure of $\mathbf{1}$ in both solvents (see Figure S6). While the diamagnetic contribution from the solvent matrix is difficult to accurately determine, we can assume that the coupling between the two $\mathrm{Cu}^{\text {II }}$ centers is insignificant at high temperature. Therefore, the diamagnetic correction was adjusted to set the value of $\chi_{\mathrm{M}} T$ to be constant in the temperature range $150-300 \mathrm{~K}$. In addition, using this assumption, the number of moles of $\mathbf{1}$ was determined through an independent measure of the $g$ tensor using EPR (see Figure S7). This method enables us to eliminate mass errors introduced during the preparation of such a small sample.

Electron paramagnetic resonance experiments. Continuous-wave EPR data were collected on

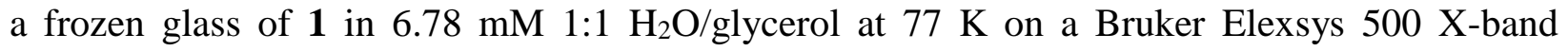
spectrometer at the University of Chicago EPR facility. Spectra were acquired with the Bruker Win-EPR software suite. The spectrometer was equipped with a dual mode cavity, operating in parallel mode. 
Cyclic voltammetry. Cyclic voltammetry was carried out in a standard one-compartment cell in air at ambient temperature, equipped with a glassy carbon working electrode, a platinum wire as counter electrode, and a $\mathrm{Ag} / \mathrm{AgCl}$ in saturated $\mathrm{KCl}$ solution reference electrode using a $\mathrm{CHI} 760 \mathrm{c}$ potentiostat. The analyte solution was prepared with $0.1 \mathrm{M} \mathrm{NaClO}_{4}$ aqueous solution at $\mathrm{pH}$ 7. The voltammogram was converted and shown as values referred to the normal hydrogen electrode (NHE), using a literature conversion factor. ${ }^{8}$

UV/Visible spectral titrations. Spectral titration experiments were carried out on an Agilent Cary $5000 \mathrm{UV} / \mathrm{Vis} / \mathrm{NIR}$ spectrometer. In general, $2 \mu \mathrm{L}$ increments of an aqueous stock solution of $\mathrm{Cu}\left(\mathrm{NO}_{3}\right)_{2} \cdot 3 \mathrm{H}_{2} \mathrm{O}$ and $\mathrm{K}_{4}\left(\mathrm{P}_{2} \mathrm{O}_{7}\right)$ were added to a $3 \mathrm{~mL}$ solution of $\mathrm{HL}$. Each spectrum was acquired after stirring for $3 \mathrm{~min}$ following each addition. The absorbance value was corrected for the change of volume of the sample by the addition of a stock solution. Typical starting samples for dinuclear complexes contained $0.317 \mathrm{mM}$ of $\mathrm{HL}$ or $0.317 \mathrm{mM}$ of $\mathrm{HL}+0.634 \mathrm{mM}$ of $\mathrm{Cu}\left(\mathrm{NO}_{3}\right)_{2} \cdot 3 \mathrm{H}_{2} \mathrm{O}$ in 5 $\mathrm{mM}$ HEPES at $\mathrm{pH}$ 7. Typical stock solutions contained $50.1 \mathrm{mM}$ of $\mathrm{Cu}^{2+}$ in deionized water or $48.8 \mathrm{mM}$ of $\mathrm{K}_{4}\left(\mathrm{P}_{2} \mathrm{O}_{7}\right)$ in $5 \mathrm{mM}$ HEPES $\mathrm{pH}$ 7. The titration data for the dissociation constant of $\mathrm{P}_{2} \mathrm{O}_{7}{ }^{4-}$ were fitted by the program Dynafit ${ }^{9}$ using the follow script:

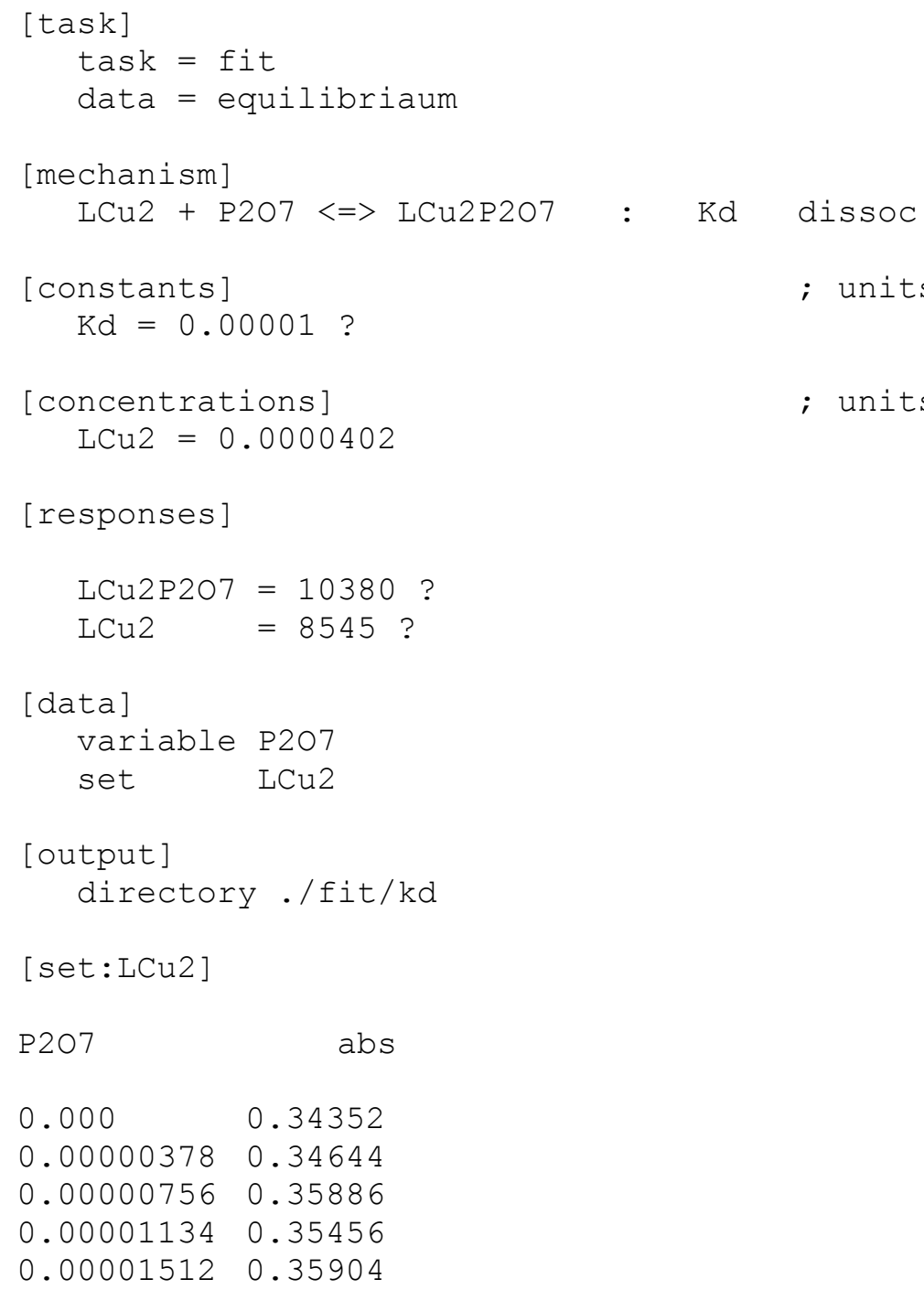




$\begin{array}{ll}0.0000189 & 0.36894 \\ 0.00002268 & 0.37316 \\ 0.00002646 & 0.38281 \\ 0.00003024 & 0.38669 \\ 0.00003402 & 0.38686 \\ 0.0000378 & 0.38557 \\ 0.00004158 & 0.39611 \\ 0.00004536 & 0.4003 \\ 0.00004914 & 0.39925 \\ 0.00005292 & 0.39943 \\ 0.0000567 & 0.4018 \\ 0.00007182 & 0.41745 \\ 0.0000756 & 0.41544 \\ 0.00009072 & 0.41559 \\ 0.00010584 & 0.41649 \\ 0.00012096 & 0.421 \\ 0.00013608 & 0.42204 \\ 0.0001512 & 0.42078 \\ 0.00016632 & 0.41314 \\ 0.00018144 & 0.41725 \\ {[\text { end] }} & \end{array}$


Table S1 | Crystallographic data for $\mathbf{1}$.

\begin{tabular}{|c|c|}
\hline & 1 \\
\hline Empirical formula & $\mathrm{C}_{34} \mathrm{H}_{62} \mathrm{Cu}_{4} \mathrm{KN}_{13} \mathrm{O}_{33} \mathrm{P}_{4}$ \\
\hline Formula weight, $\mathrm{g} \mathrm{mol}^{-1}$ & 1598.10 \\
\hline Crystal system & Triclinic \\
\hline Space group & $P-1$ \\
\hline Wavelength, $\AA$ & 0.71073 \\
\hline Temperature, $\mathrm{K}$ & 100 \\
\hline$a, \AA$ & $10.4003(9)$ \\
\hline$b, \AA$ & $16.0666(13)$ \\
\hline$c, \AA$ & $21.6870(18)$ \\
\hline$\alpha,^{o}$ & $106.880(4)$ \\
\hline$\beta,{ }^{\circ}$ & $91.828(4)$ \\
\hline$\gamma,{ }^{o}$ & $90.151(4)$ \\
\hline$V, \AA^{3}$ & $3465.7(5)$ \\
\hline$Z$ & 2 \\
\hline$\rho_{\text {calcd }}, \mathrm{Mg} \mathrm{m}^{-3}$ & 1.531 \\
\hline$\mu, \mathrm{mm}^{-1}$ & 1.452 \\
\hline Refections coll./unique & $54176 / 16420$ \\
\hline$R_{\text {int }}$ & 0.0357 \\
\hline${ }^{\mathrm{a}} R_{1}(I>2 \sigma(I))$ & 0.0705 \\
\hline${ }^{{ }^{\mathrm{w}}} R_{2}$ (all) & 0.2169 \\
\hline GoF & 1.043 \\
\hline
\end{tabular}

${ }^{\mathrm{a}} R_{1}=\Sigma|| F_{0}|-| F_{\mathrm{C}}|| / \Sigma\left|F_{0}\right|$

$\mathrm{b}_{w R_{2}}=\left[\Sigma \mathrm{w}\left(F_{0}{ }^{2}-F_{\mathrm{C}}{ }^{2}\right)^{2} / \Sigma \mathrm{w}\left(F_{\mathrm{o}}{ }^{2}\right)^{2}\right]^{1 / 2}$ 

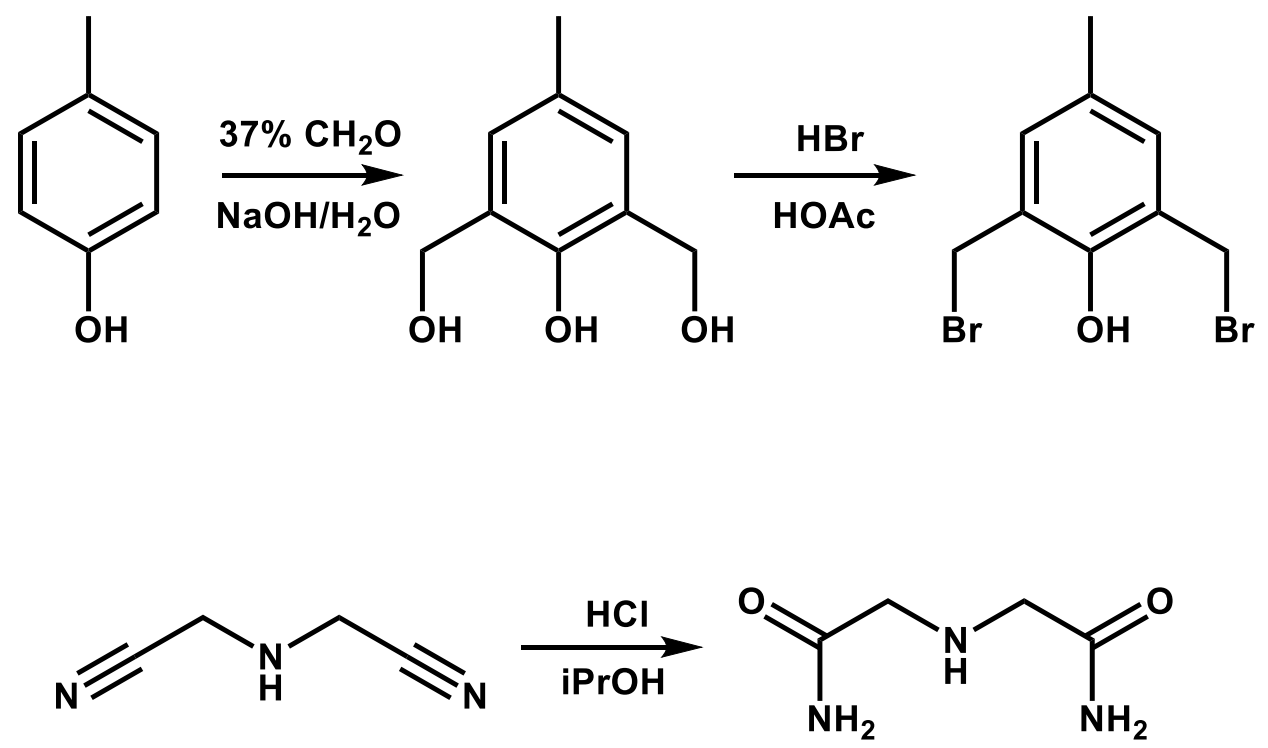

Scheme S1. Synthesis of precursors for HL. 


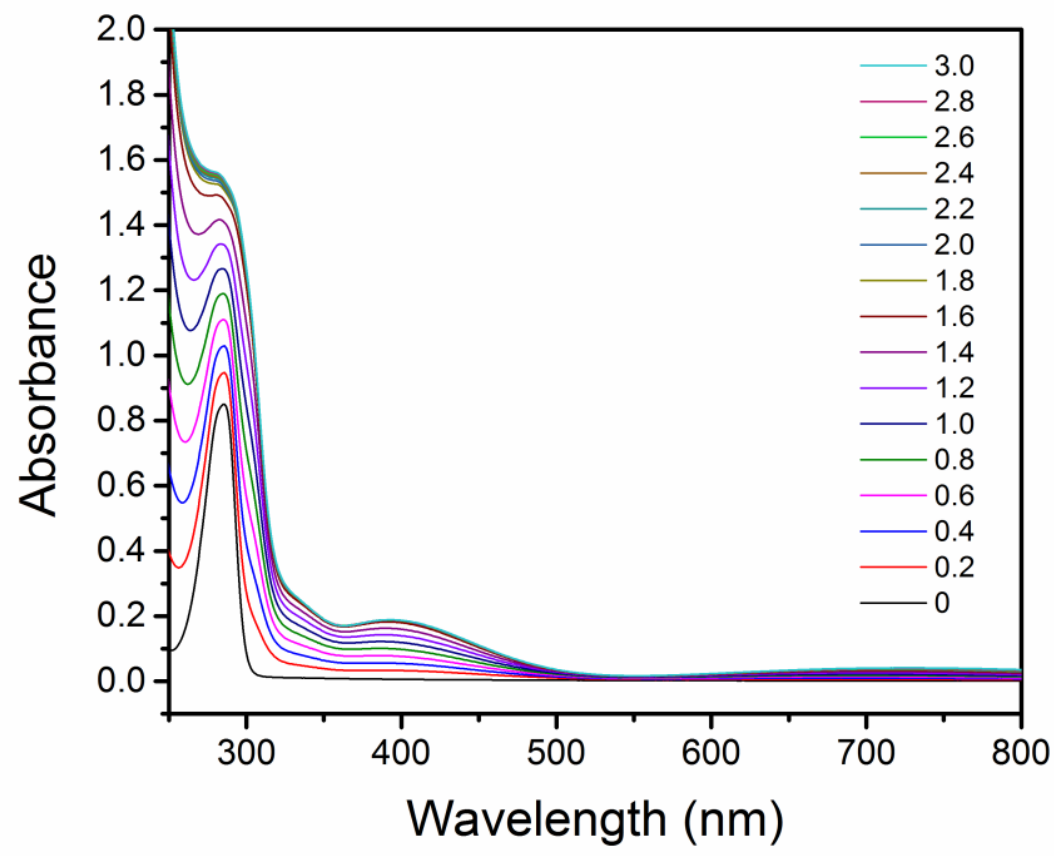

Figure S1. UV/Visible spectra of a solution containing $0.317 \mathrm{mM}$ of HL and $5 \mathrm{mM}$ of HEPES at $\mathrm{pH} \mathrm{7,} \mathrm{with} \mathrm{incremental} \mathrm{additions} \mathrm{of} \mathrm{a} 50 \mathrm{mM}$ aqueous solution of $\mathrm{Cu}\left(\mathrm{NO}_{3}\right)_{2} \cdot 3 \mathrm{H}_{2} \mathrm{O}$. Total numbers of stoichiometric equivalents of $\mathrm{Cu}$ corresponding to each addition are given in the legend. 


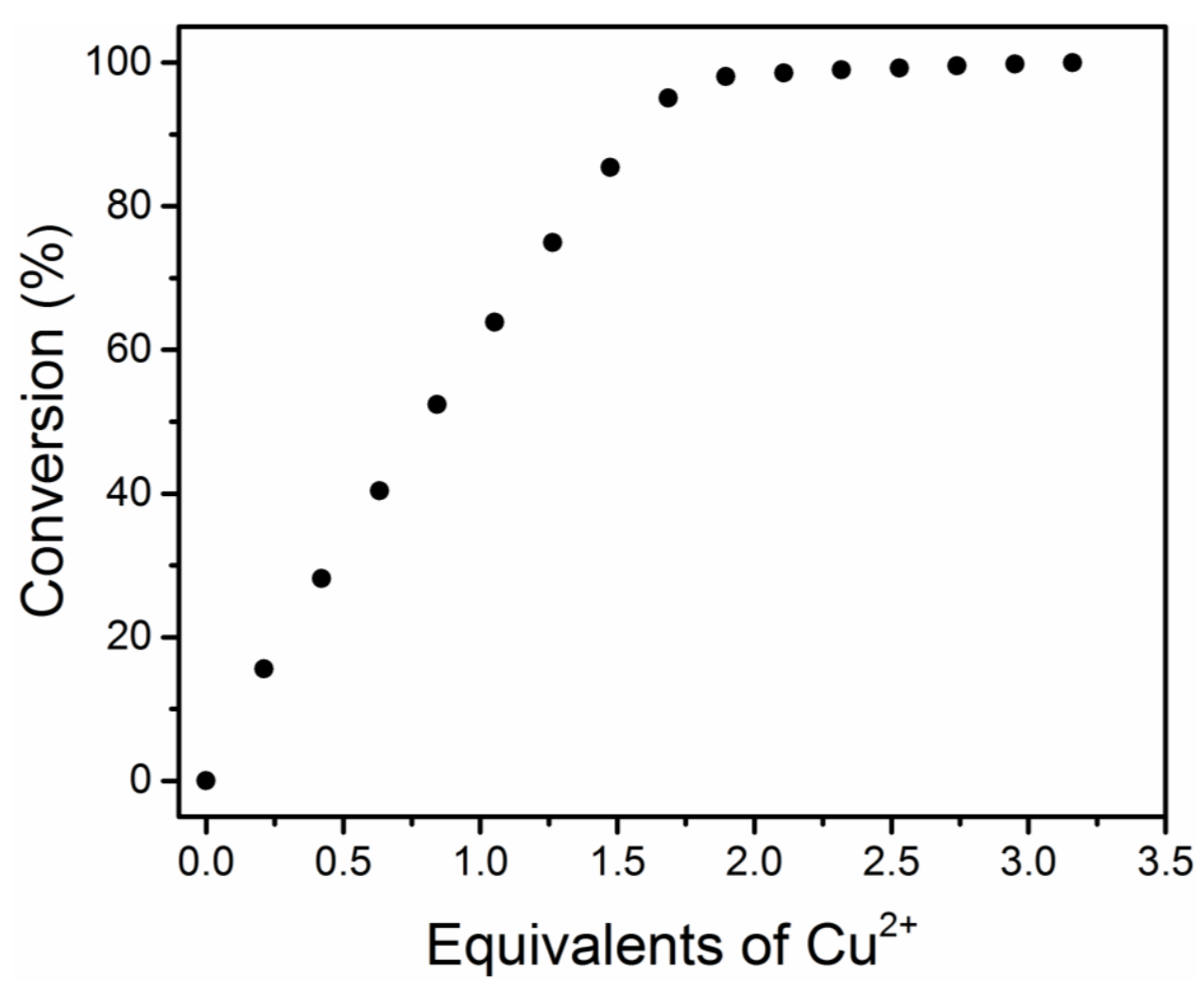

Figure S2. Reaction of $\mathrm{HL}$ with $\mathrm{Cu}^{\mathrm{II}}$, as monitored by the appearance of a peak at $398 \mathrm{~nm}$ in the UV/Visible spectra. 


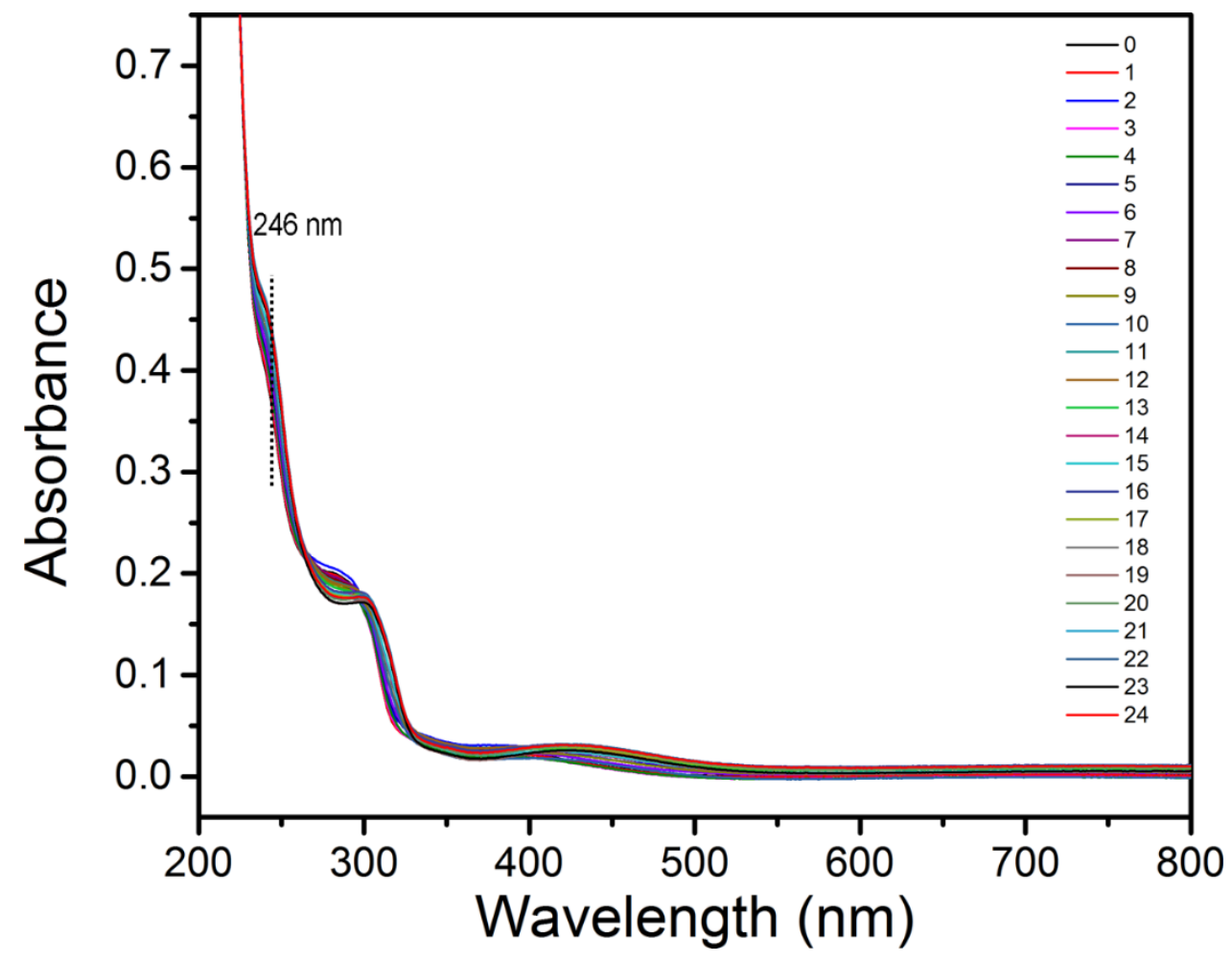

Figure S3. UV/Visible spectra of a solution containing $40.2 \mu \mathrm{M}$ of HL with 2 eq. of $\mathrm{Cu}^{\mathrm{II}}$ and $300 \mu \mathrm{M}$ of HEPES at $\mathrm{pH} 7$, with incremental additions of a $5.67 \mathrm{mM}$ ( $1^{\text {st }}$ to $15^{\text {th }}$ addition $)$ or $17.0 \mathrm{mM}$ (16 $6^{\text {th }}$ to $24^{\text {th }}$ addition $)$ of $\mathrm{K}_{2} \mathrm{P}_{2} \mathrm{O}_{7}$ in the same buffer. Color assignments of each addition are given in the legend. Dotted line indicates the location of $246 \mathrm{~nm}$ absorbance which is used in Figure S6 for fitting. 


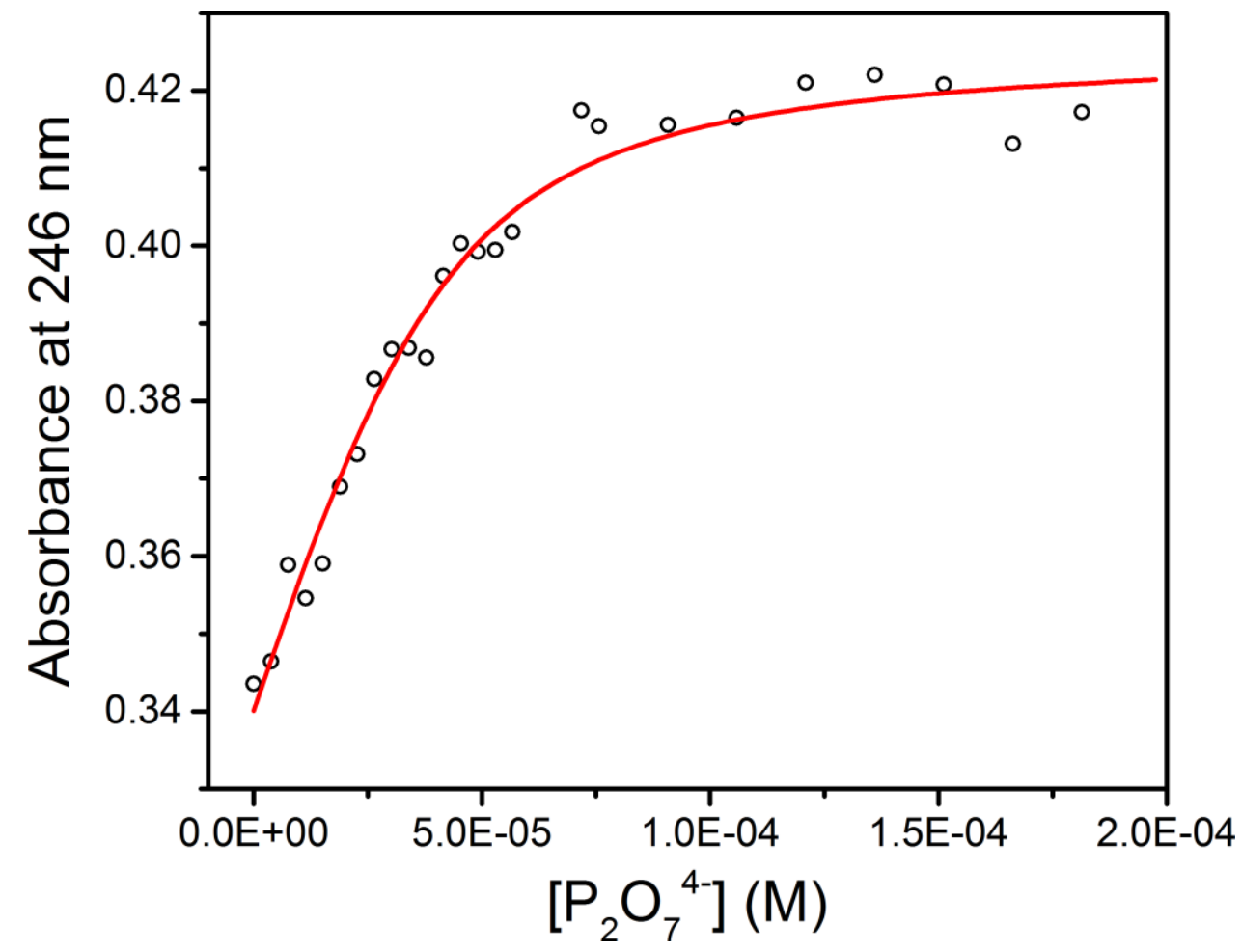

Figure S4. The absorbance at $246 \mathrm{~nm}$ of each spectrum in Figure S5 are plotted against the concentration of $\mathrm{P}_{2} \mathrm{O}_{7}{ }^{4-}$ added. The plot was fitted to obtain the dissociation constant of $\left[\mathrm{LCu}_{2}\left(\mathrm{P}_{2} \mathrm{O}_{7}\right)\right]^{-}$. Black circles represent experimental data; red line represent the fit. 


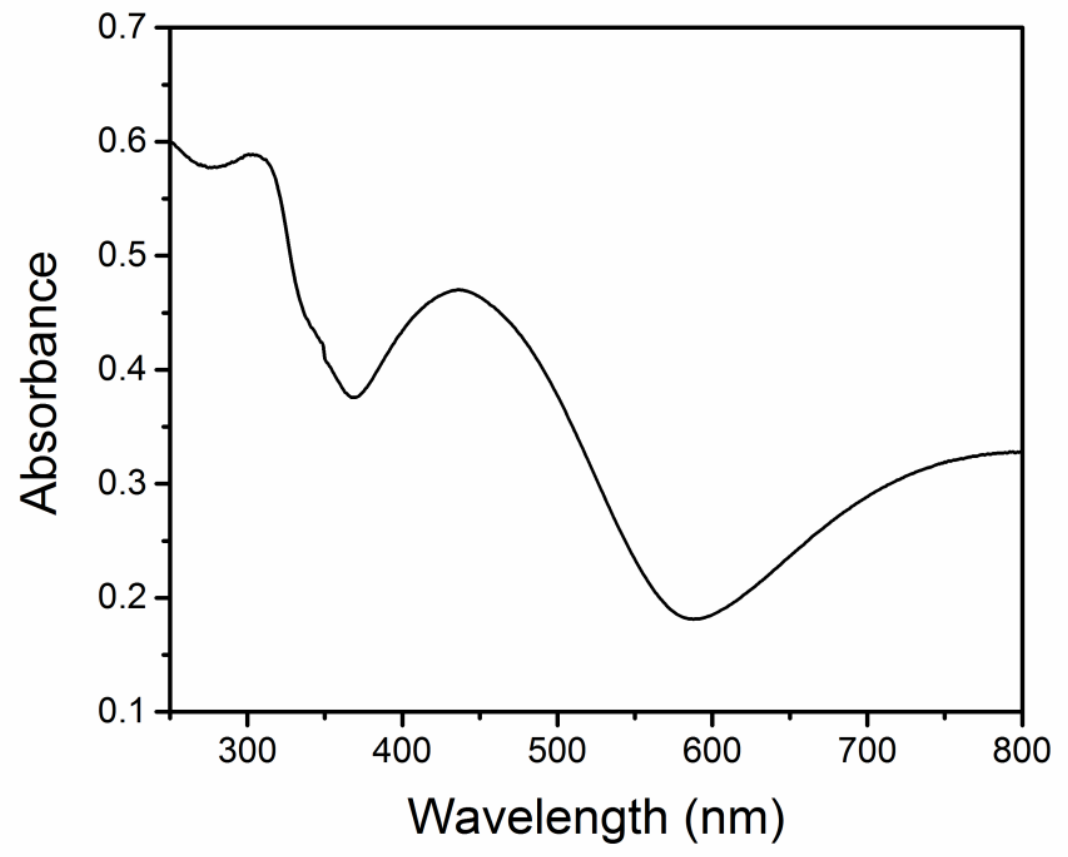

Figure S5. Diffuse-reflectance spectrum for a solid sample of $\mathbf{1}$. 


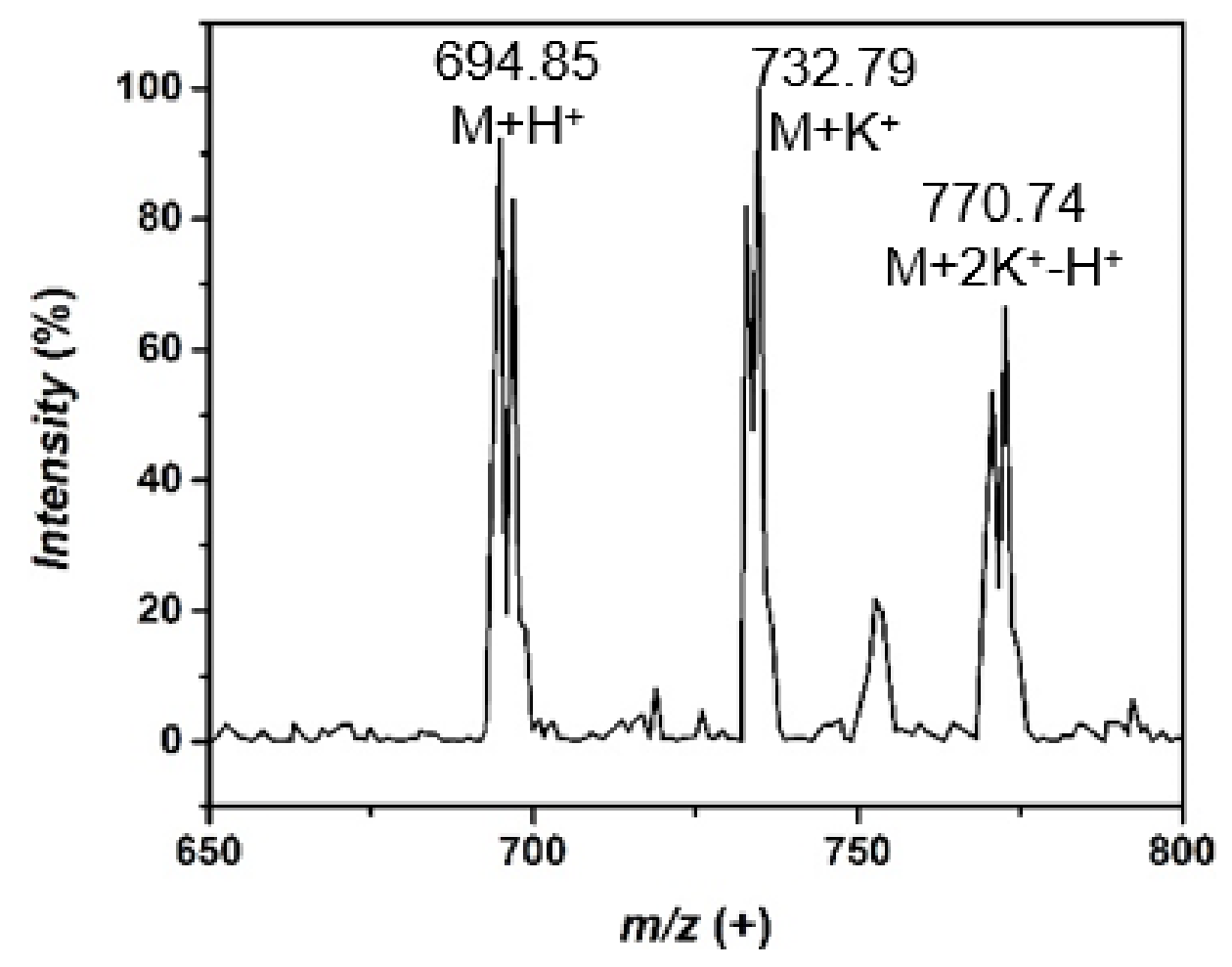

Figure S6. Electrospray ionization mass spectrum of $\mathbf{1}$ in $\mathrm{H}_{2} \mathrm{O}$, where $\mathrm{M}=$ $\mathrm{H}\left[\mathrm{LCu}_{2}\left(\mathrm{P}_{2} \mathrm{O}_{7}\right)\right]$. 


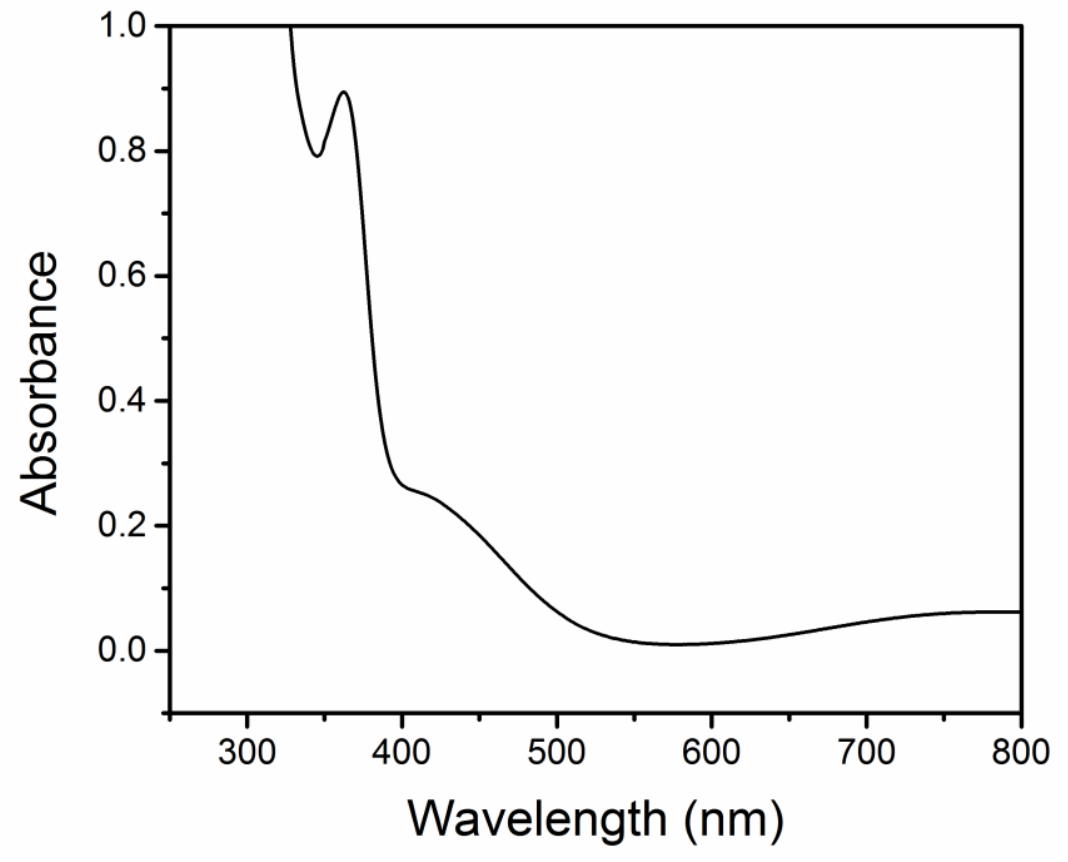

Figure S7. UV/Visible spectrum of $0.832 \mathrm{mM}$ of 2 in $3 \mathrm{mM}$ HEPES buffer solution at $\mathrm{pH} 7$. 


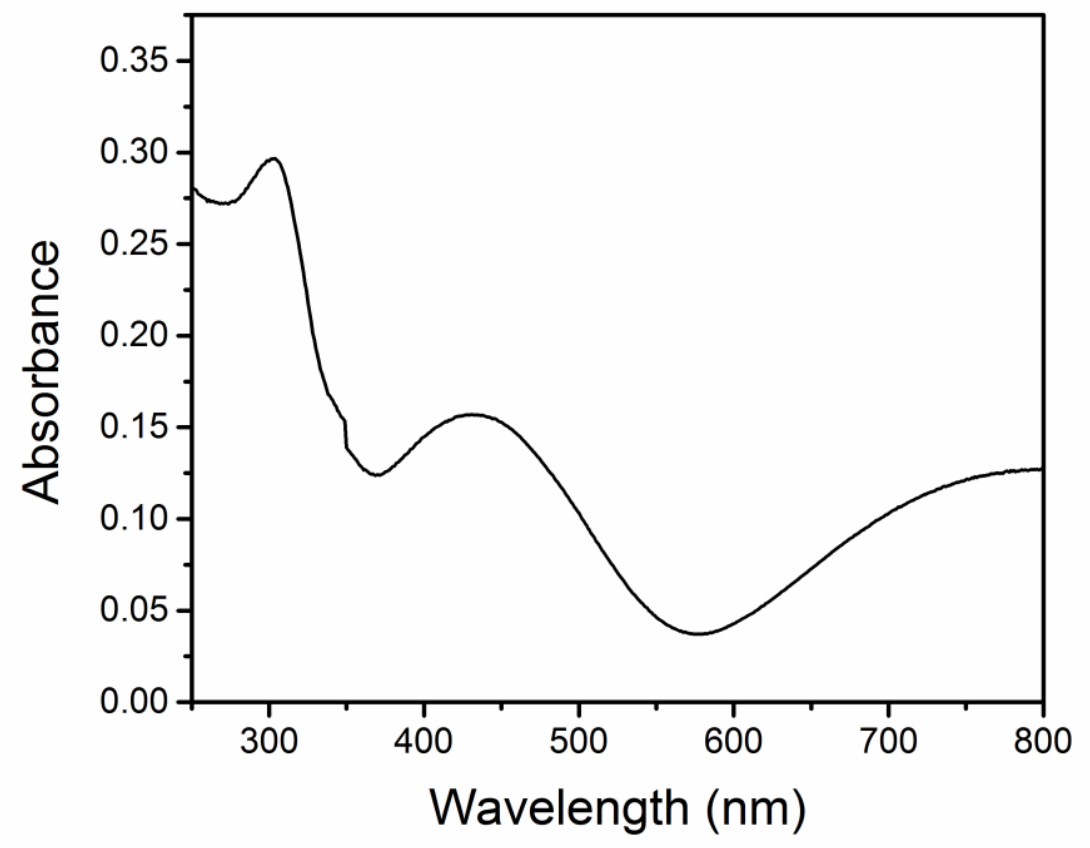

Figure S8. Diffuse-reflectance spectrum for a solid sample of $\mathbf{2}$. 


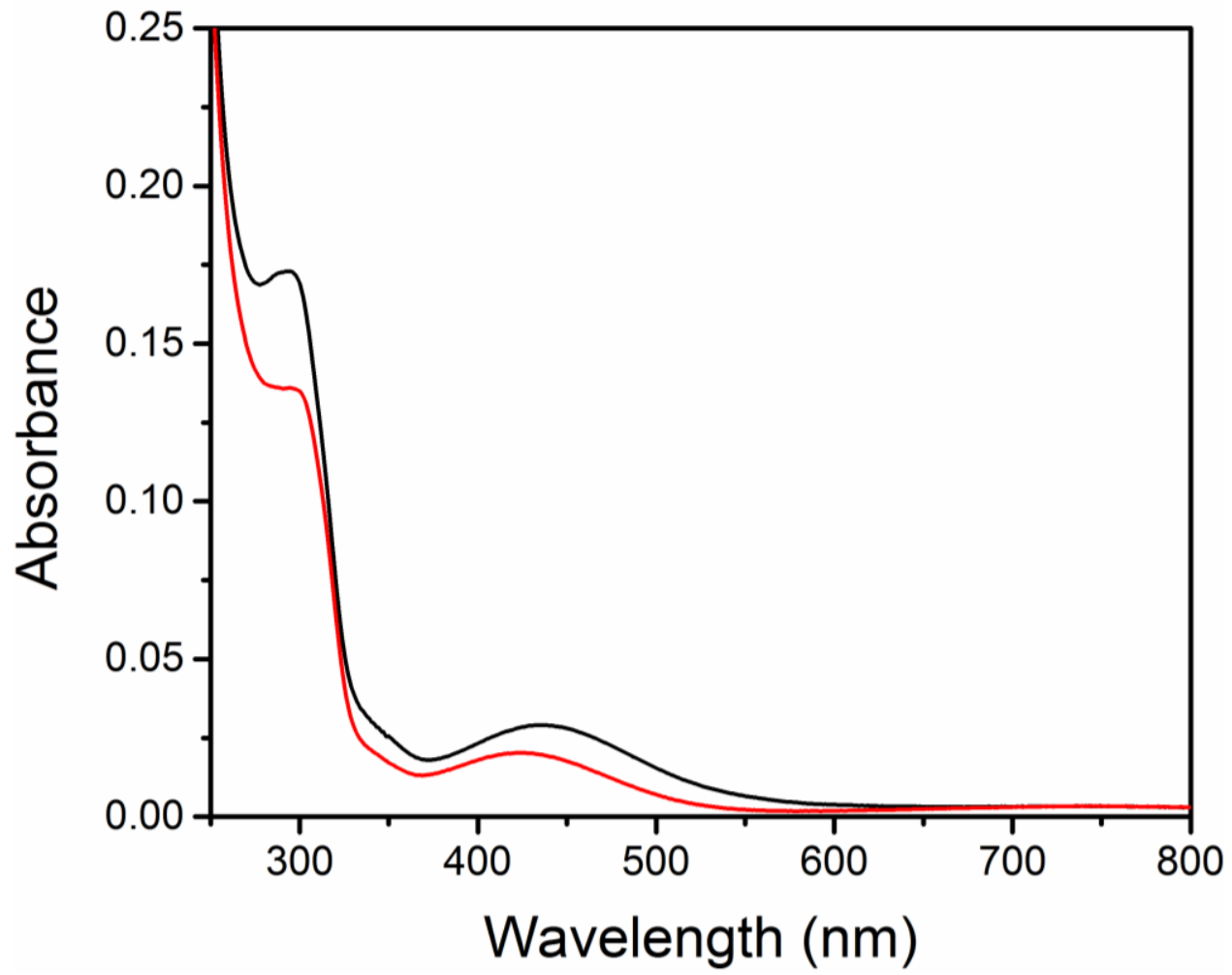

Figure S9. UV/Visible spectra of $0.317 \mathrm{mM}$ of $\mathbf{1}$ in $\mathrm{H}_{2} \mathrm{O}$ (black) and in 1:1 $\mathrm{H}_{2} \mathrm{O}$ /glycerol (red). 


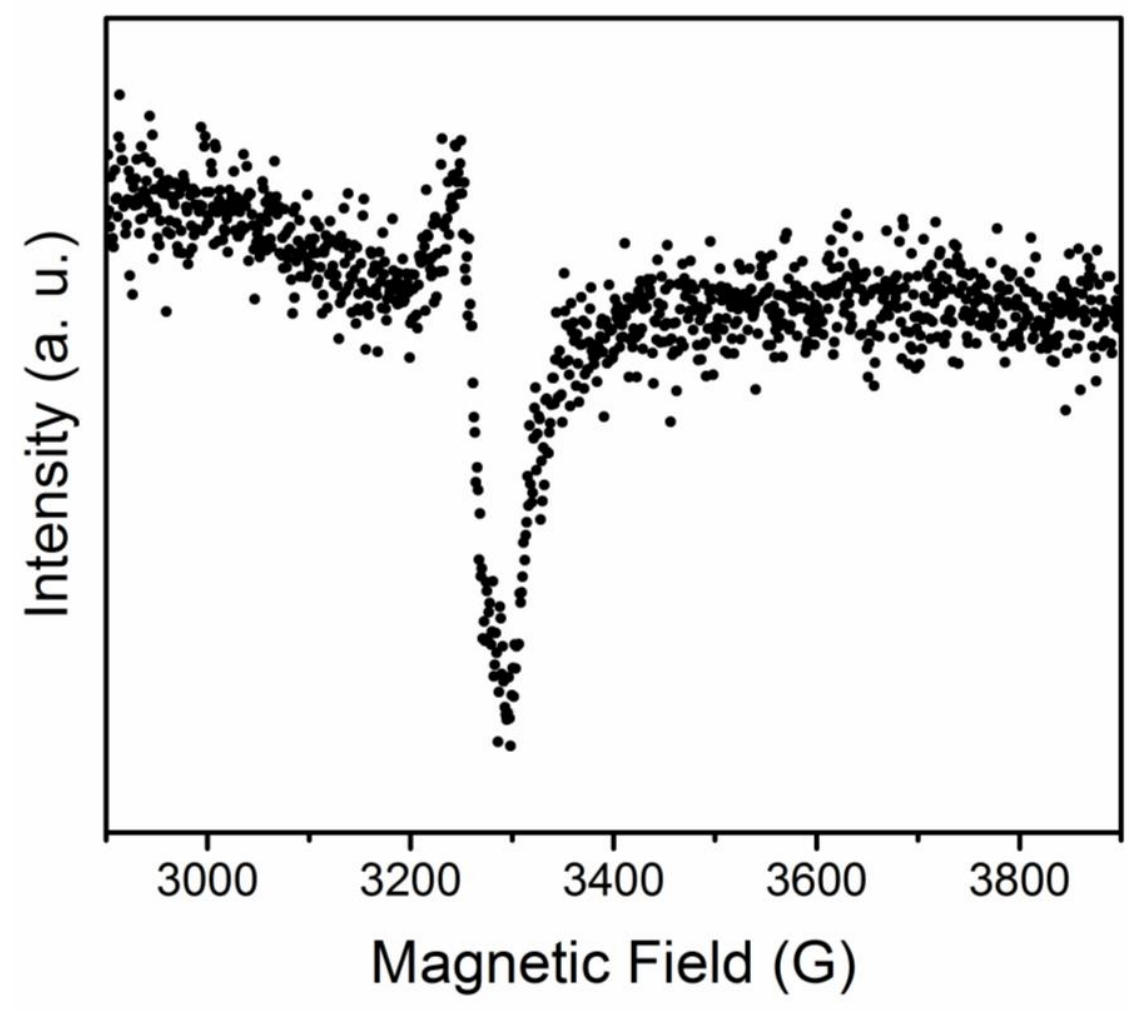

Figure S10. X-band EPR spectrum of 1 in a 1:1 $\mathrm{H}_{2} \mathrm{O} /$ glycerol solution at $77 \mathrm{~K}$. 


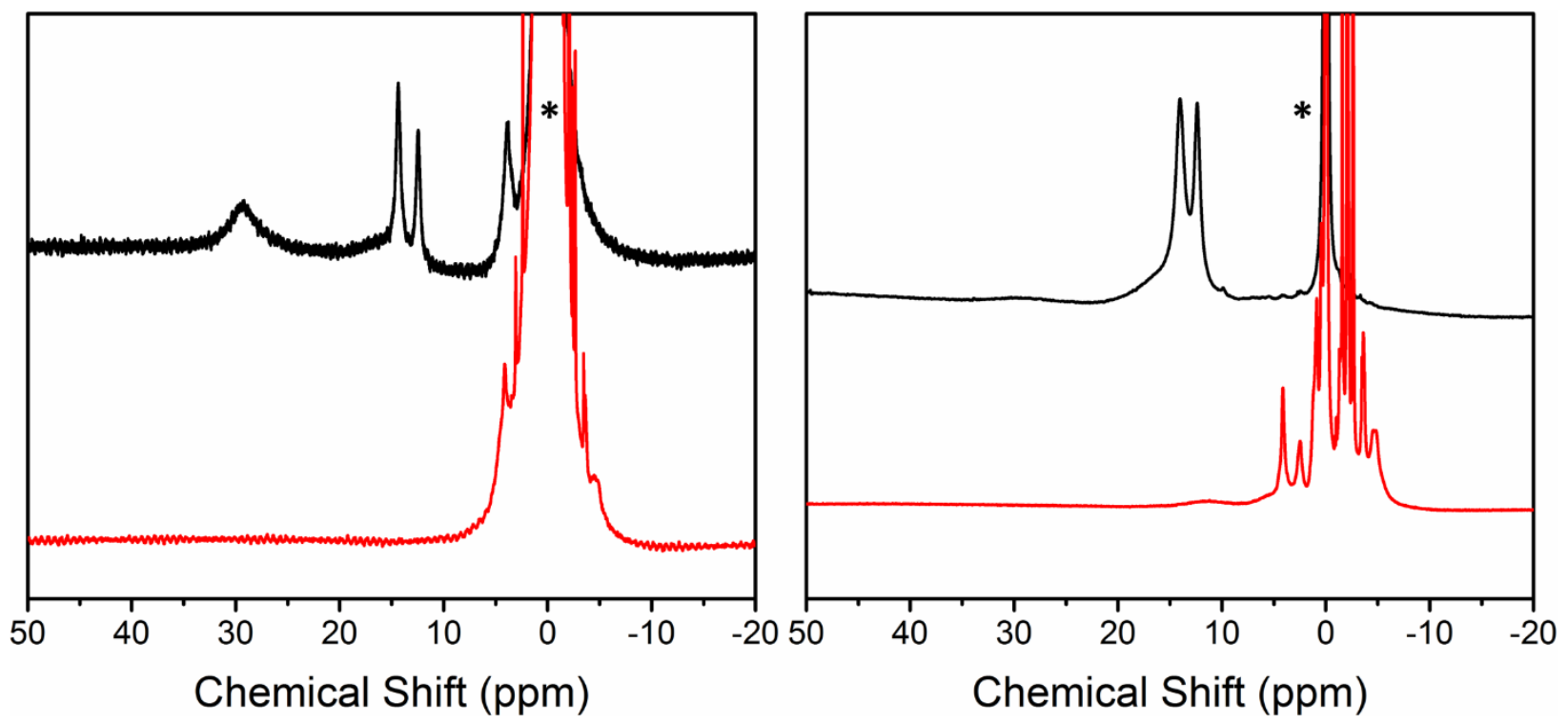

Figure S11. ${ }^{1} \mathrm{H}$ NMR spectra of 1 (black) and 2 (red) in $\mathrm{D}_{2} \mathrm{O}$ (left) and $30 \mathrm{mM} \mathrm{HEPES} \mathrm{H}_{2} \mathrm{O}$ buffer (right) at $\mathrm{pH} 7$ at $37^{\circ} \mathrm{C}$. Asterisks denote solvent peaks. 


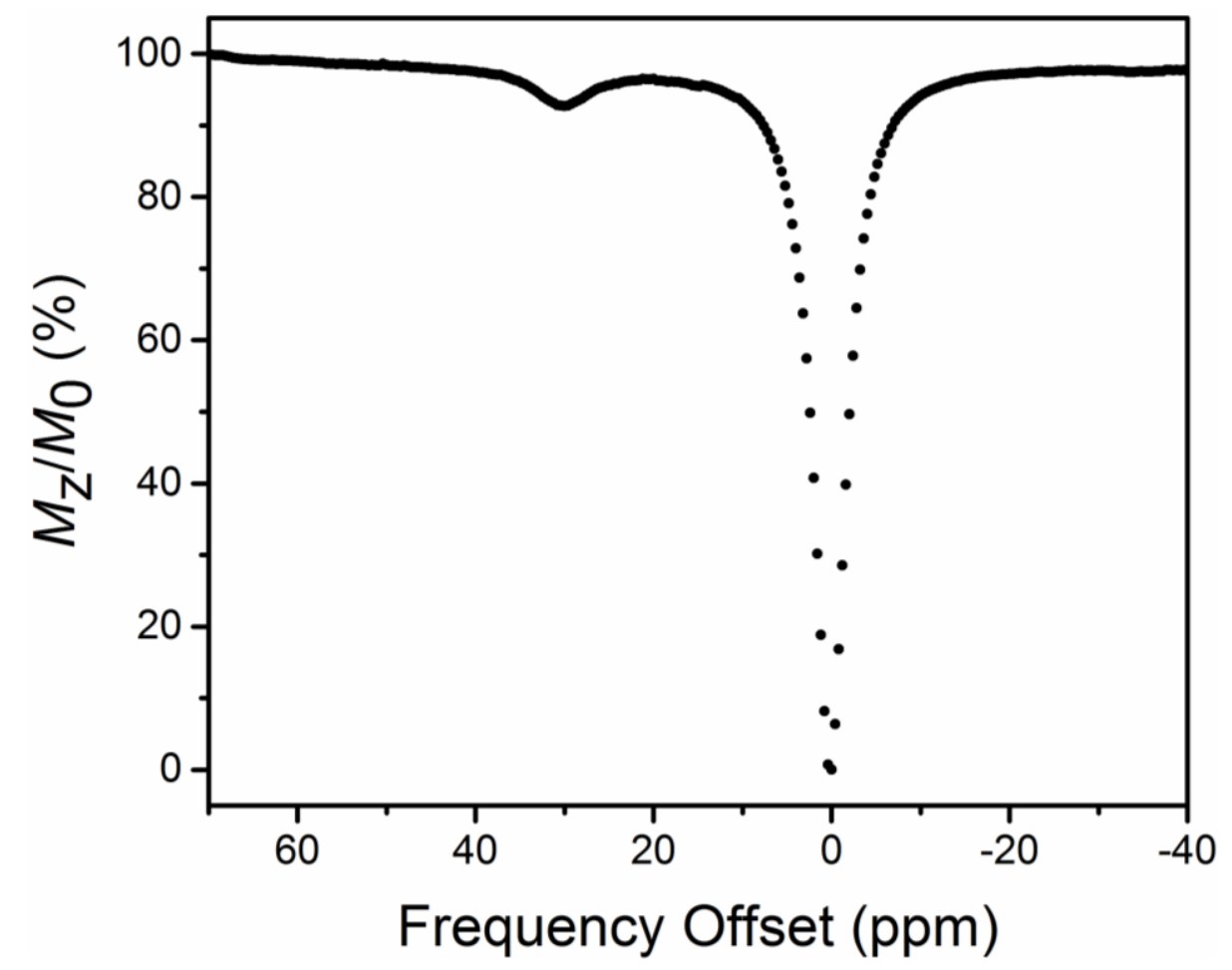

Figure S12. CEST spectrum of $50 \mathrm{mM}$ of HEPES containing $10 \mathrm{mM}$ of 1 at $\mathrm{pH} 7$ and $25^{\circ} \mathrm{C}$. 


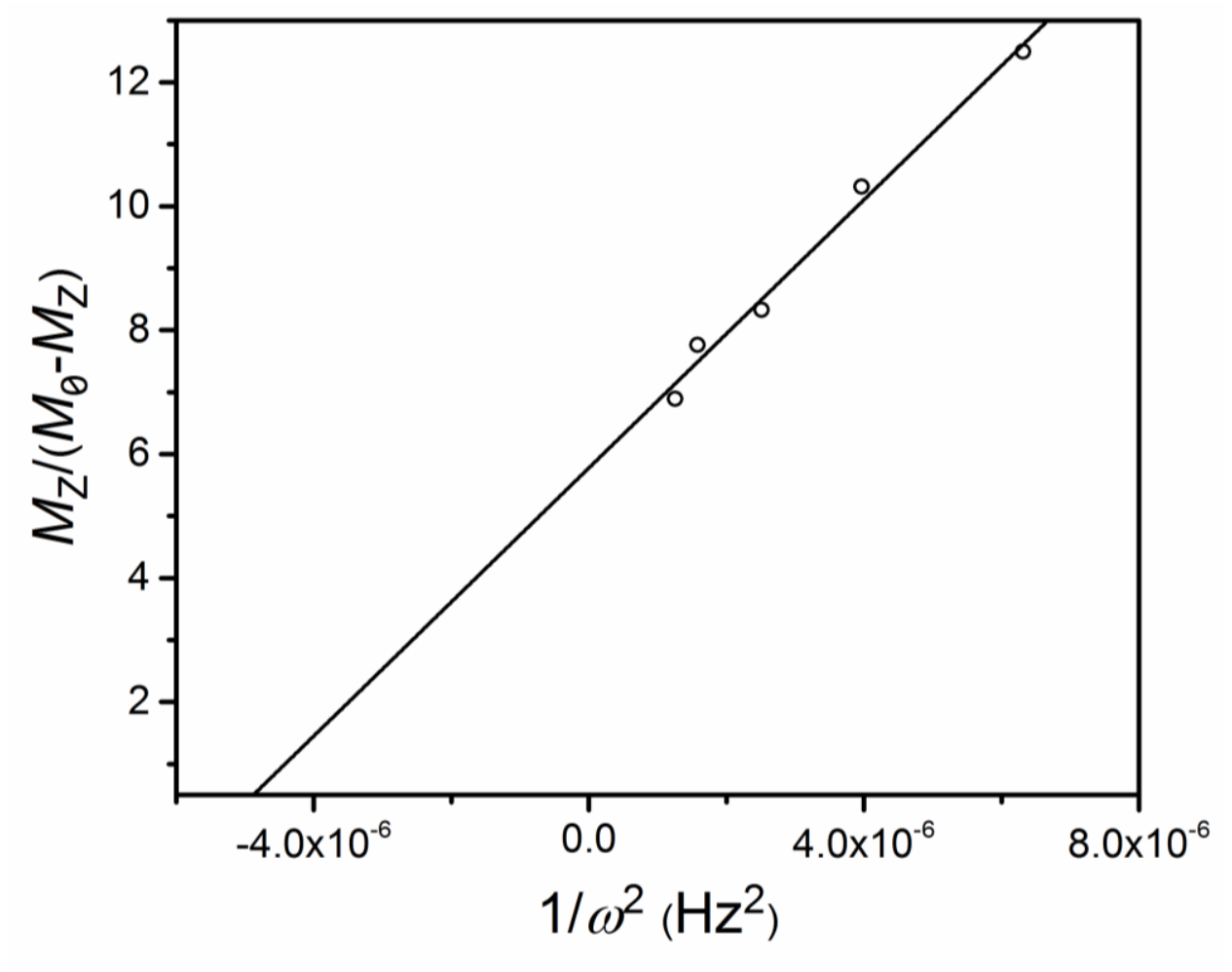

Figure S13. Omega plot of $M_{\mathrm{Z}} /\left(M_{0}-M_{\mathrm{Z}}\right)$ versus $1 / \omega^{2}$, recorded at $11.75 \mathrm{~T}$ for $10 \mathrm{mM}$ of 1 at $37^{\circ} \mathrm{C}$, using $5 \mathrm{~s}$ presaturation pulse. 


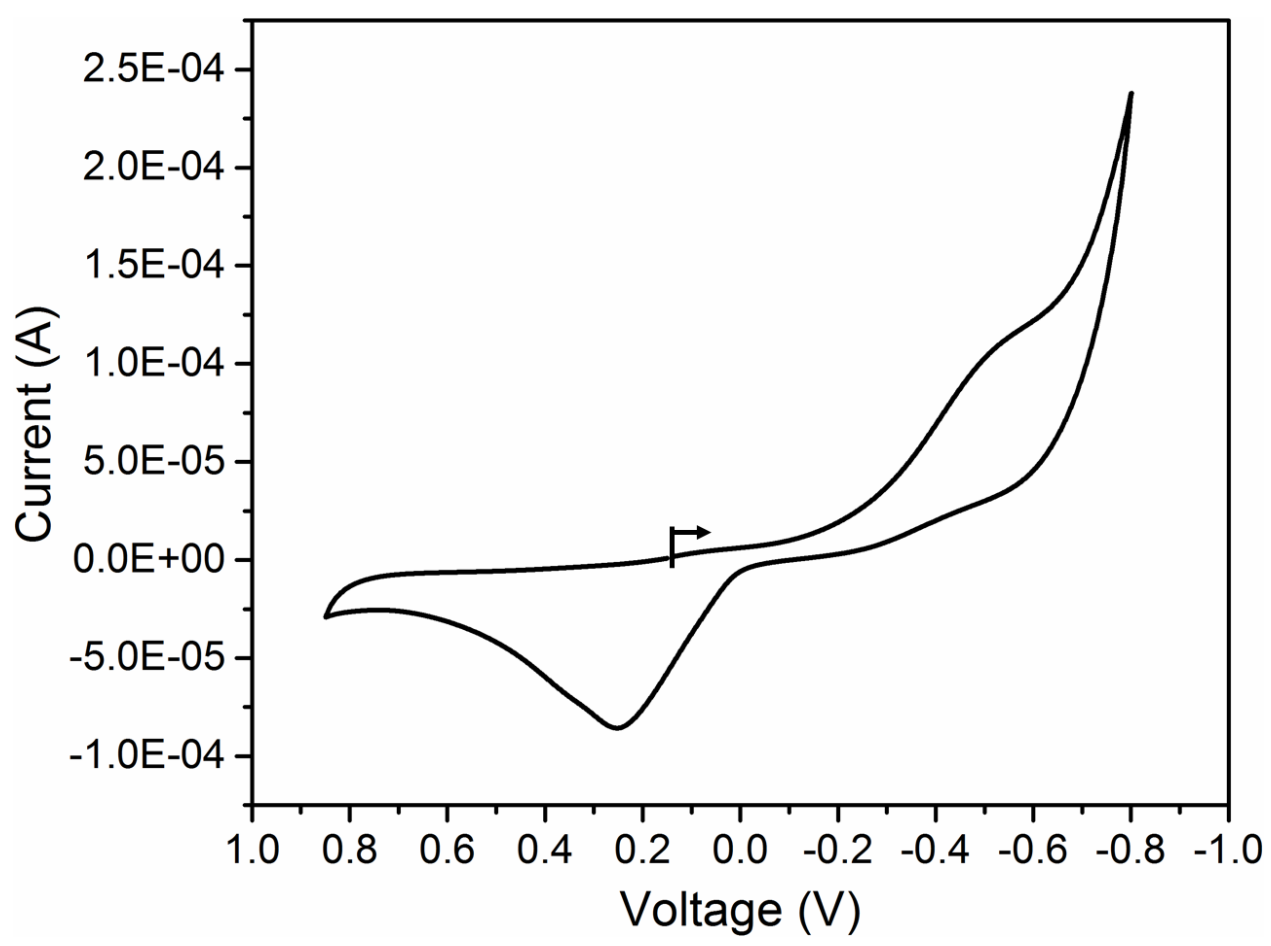

Figure S14. Cyclic voltammogram for $20 \mathrm{mM} 1$ in aqueous solution at $\mathrm{pH}$ 7 , using a glassy carbon electrode, $10 \mathrm{mV} / \mathrm{s}$ scan rate and $0.1 \mathrm{M} \mathrm{NaClO}_{4}$ supporting electrolyte. 


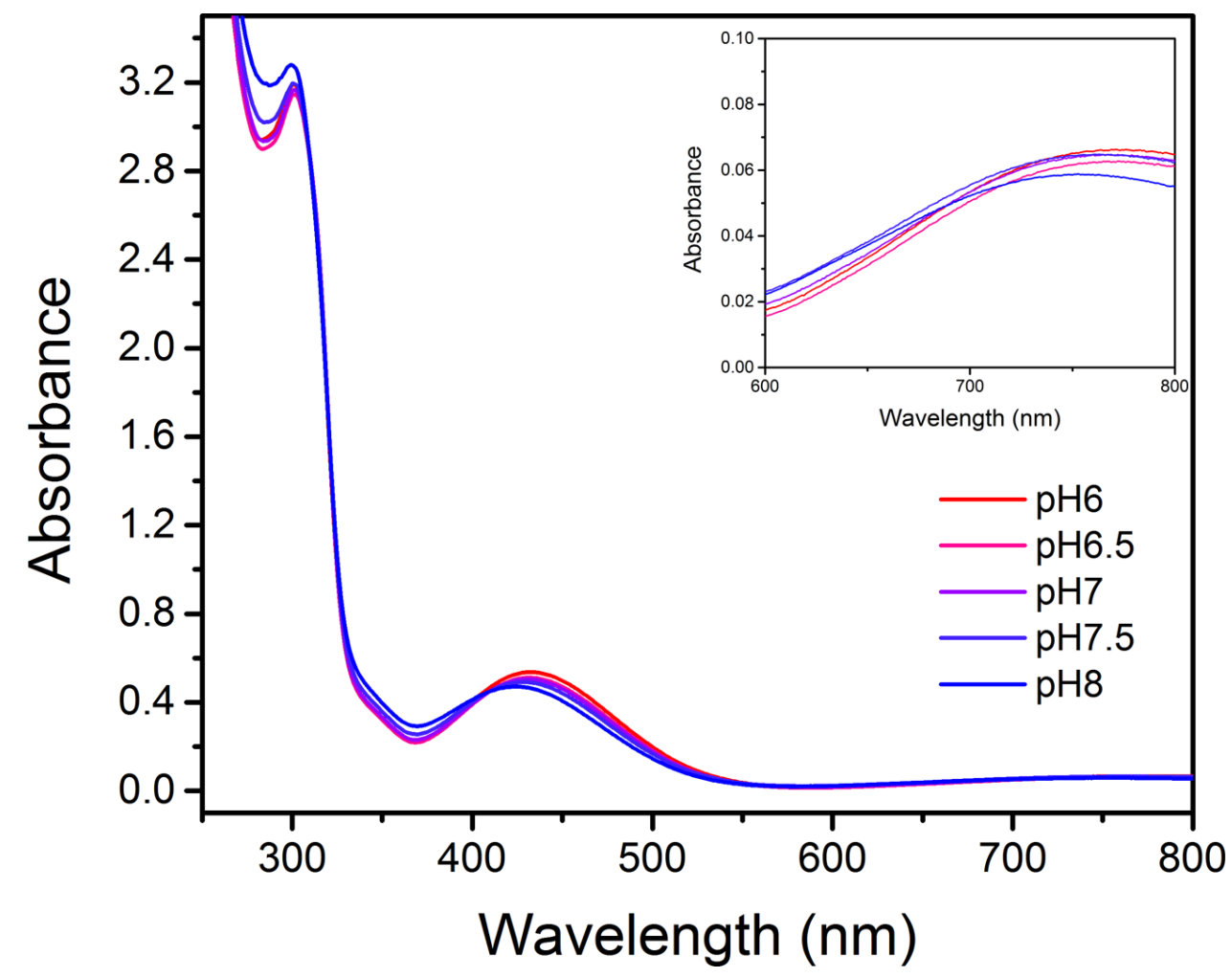

Figure S15. UV/Visible spectra for solutions containing $0.8 \mathrm{mM}$ of 1 buffered at different $\mathrm{pH}$ values. Buffers contain $3 \mathrm{mM}$ of MES ( $\mathrm{pH}$ 6) or HEPES ( $\mathrm{pH} \mathrm{6.5,} \mathrm{7,} 7.5$ and 8). Inset shows the region for $\mathrm{d}-\mathrm{d}$ transitions. 


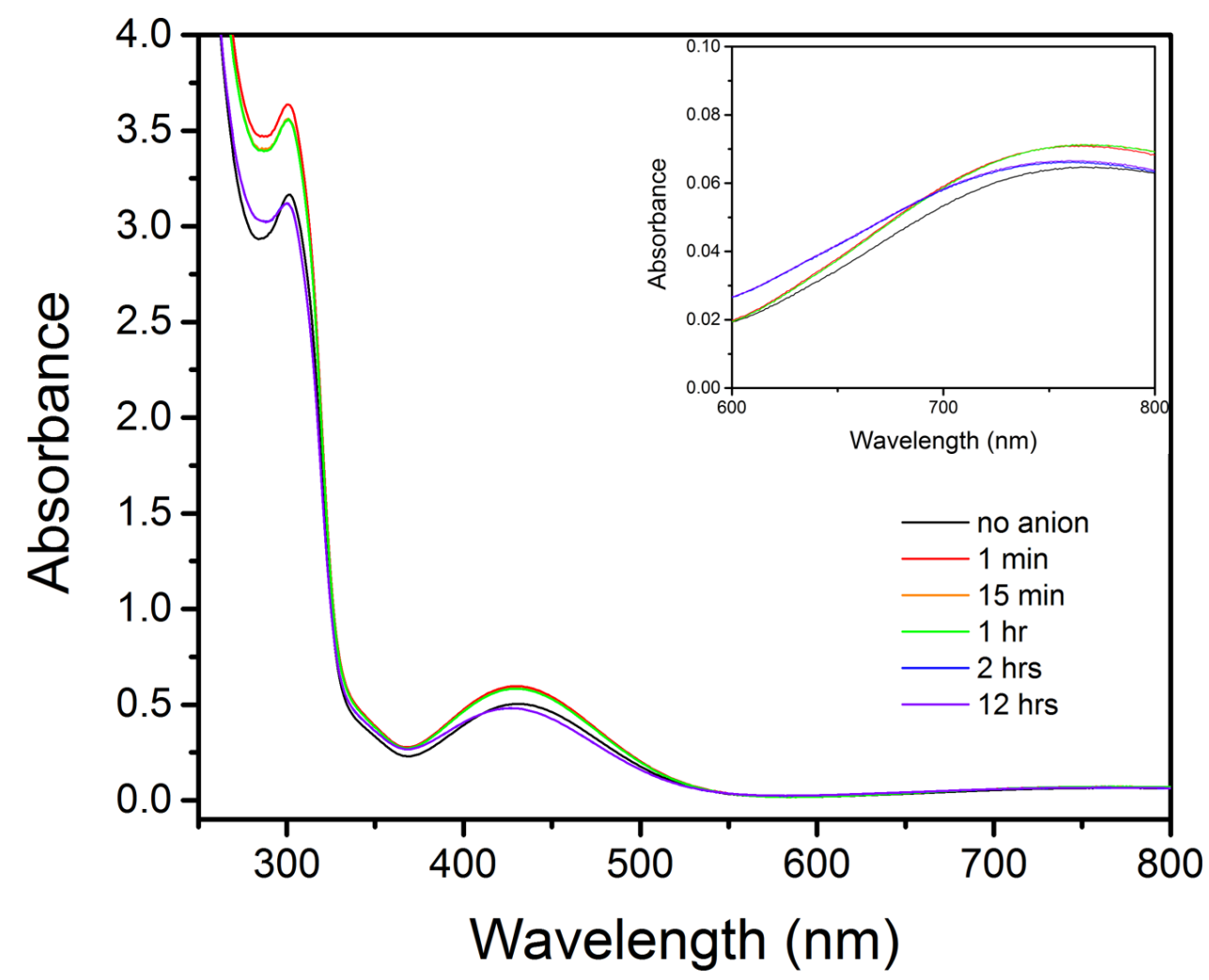

Figure S16. UV/Visible spectra for solutions containing $0.8 \mathrm{mM}$ of 1, $4 \mathrm{mM}$ of $\mathrm{Na}_{2} \mathrm{CO}_{3}$ and $\mathrm{NaH}_{2} \mathrm{PO}_{4}$, and $3 \mathrm{mM}$ HEPES buffered at $\mathrm{pH}$ 7. The color assignment in the legend correspond to spectra with different incubation times. Inset shows region for the $d-d$ transitions. 


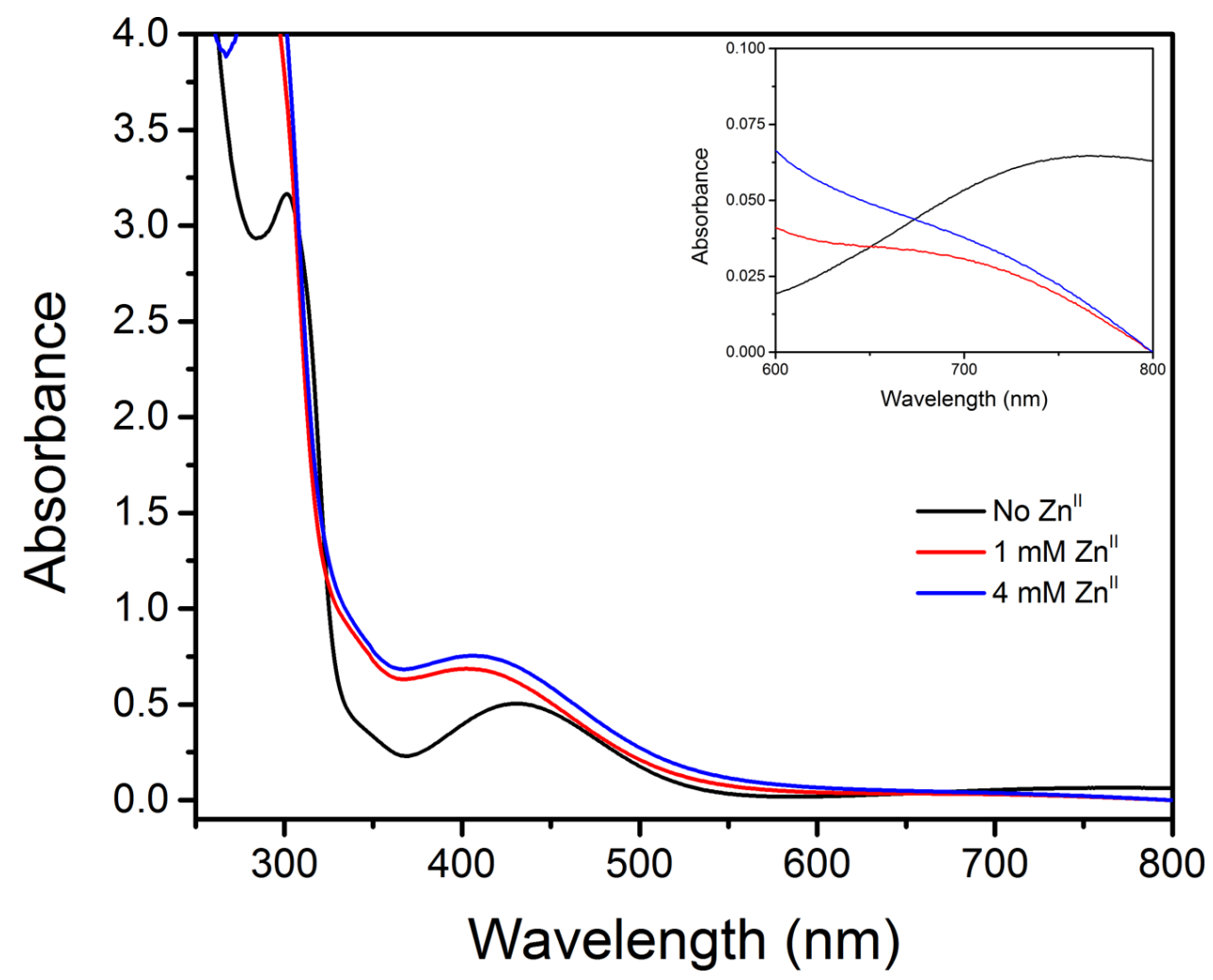

Figure S17. UV/Visible spectra for solutions containing $0.8 \mathrm{mM}$ of $\mathbf{1}$, selected concentrations of $\mathrm{Zn}\left(\mathrm{NO}_{3}\right)_{2} \cdot 6 \mathrm{H}_{2} \mathrm{O}$ and $3 \mathrm{mM}$ HEPES buffered at $\mathrm{pH}$ 7. The color assignments in the legend correspond to spectra with different $\mathrm{Zn}^{\mathrm{II}}$ concentrations. Inset shows region for the d-d transitions. 


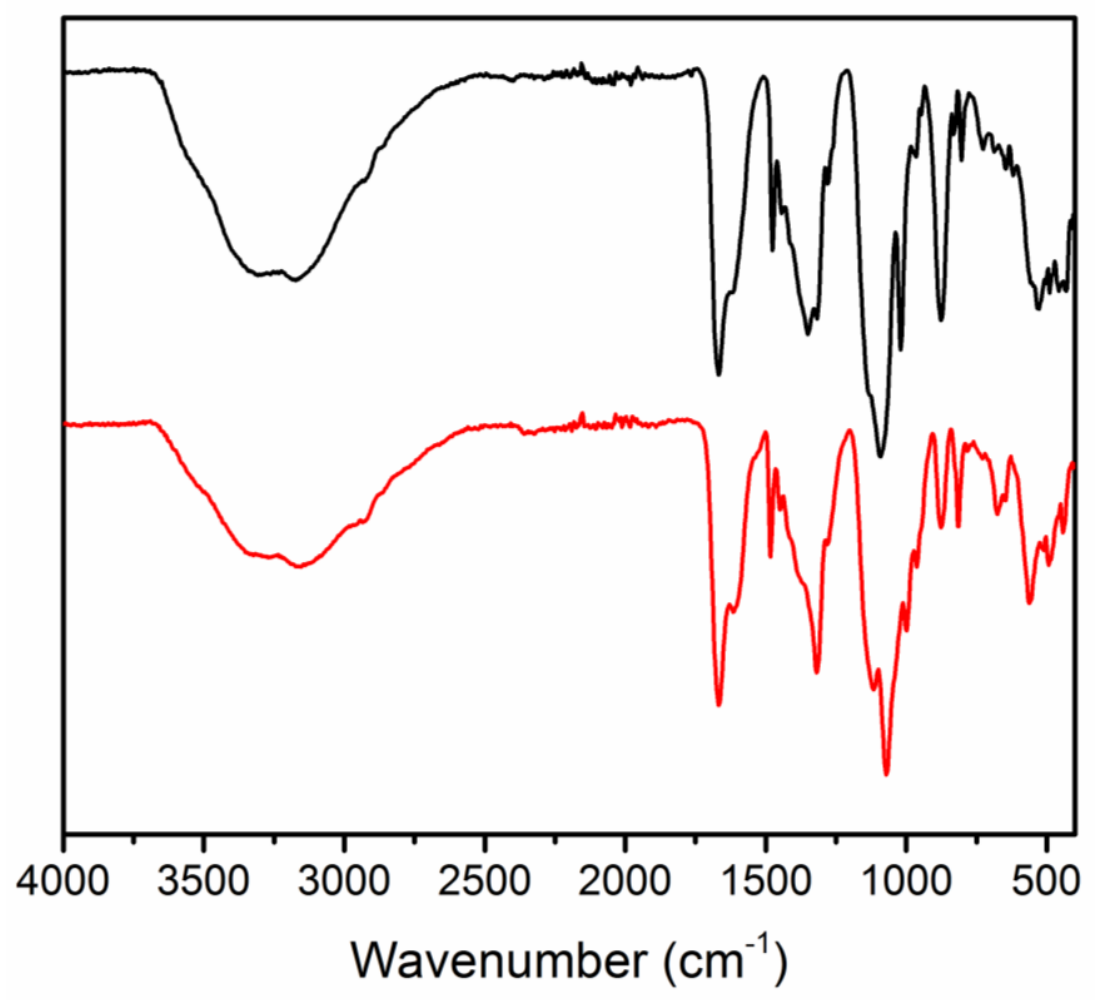

Figure S18. IR spectra of solid state samples of $\mathbf{1}$ (top) and $\mathbf{2}$ (bottom). 


\section{References}

(1) Trost, B. M.; Yeh, V. S. C.; Ito, H.; Bremeyer, N. Org. Lett. 2002, 4, 2621.

(2) Johnson, H. E.; Crosby, D. G. J. Org. Chem. 1962, 27, 798.

(3) APEX2, v. 2009 ; Bruker Analytical X-Ray Systems, Inc: Madison, WI, 2009.

(4) (a). G. M. Sheldrick, SHELXTL, Version 6.12; Bruker Analytical X-ray Systems, Inc.: Madison, WI, 2000; (b) Sheldrich, G. M. Acta Crystallogr., Sect. A: Found. Adv. 2015, 71, 3.

(5) van der Sluis, P.; Spek, A. L. Acta Crystallogr., Sect. A: Found. Crystallogr. 1990, A46, 194.

(6) Spek, A. L.; Acta Crystallogr., Sect. A: Found. Crystallogr. 1990, A46, 1.

(7) Dixon, W. T.; Ren, J.; Lubag, A. J. M.; Ratnakar, J.; Vinogradov, E.; Hancu, I.; Lenkinski, R. E.; Sherry, A. D. Magn. Reson. Med. 2010, 63, 625.

(8) Sawyer, D. T.; Sobkowiak, A. J.; Roberts, J. Electrochemistry for Chemists, $2^{\text {nd }}$ ed.; John Wiley \& Sons: New York, 1995.

(9) Kuzmič, P Anal. Biochem. 1996, 237, 260. 